\title{
SOME CALANOID COPEPODS COLLECTED CHIEFLY BY THE U.S. STEAMER ALBATROSS FROM THE PACIFIC OCEAN
}

\author{
$\operatorname{AUTHOR}(\mathrm{S}):$ \\ Tanaka, Otohiko
}

\section{CITATION:}

Tanaka, Otohiko. SOME CALANOID COPEPODS COLLECTED CHIEFLY BY THE U.S.

STEAMER ALBATROSS FROM THE PACIFIC OCEAN. PUBLICATIONS OF THE SETO MARINE BIOLOGICAL LABORATORY 1969, 17(4): 253-278

\section{ISSUE DATE:}

1969-12-27

URL:

http://hdl.handle.net/2433/175601

RIGHT: 


\section{SOME CALANOID COPEPODS COLLECTED CHIEFLY BY THE U. S. STEAMER ALBATROSS FROM THE PACIFIC OCEAN}

OTOHIKO TANAKA ${ }^{13}$

With 12 Text-figures

In my previous paper "On Euchirella (Copepoda, Calanoida) collected chiefly by the U.S. Steamer Albatross from the Pacific Ocean" (TANAKa and Omori 1968), I noted that among the species reported as Euchirella in C.B. WiLson's two papers, i.e. the Carnegie report (1942) and the Albatross report (1950), several species other than Euchirella are included. During the re-examination of specimens from the WILson Collections, deposited in the United States National Museum (USNM), the following 17 species of calanoid copepods other than Euchirella were found from 46 vials labelled as Euchirella. Among them 3 are thought to be new species, and some are rather rare ones.

Calanidae

1. Neocalanus robustior (GIESBRECHT)

2. Undinula vulgaris (DANA)

Aetideidae

3. Gaidius species

4. ? Gaetanus armiger Giesbrecht

5. * Gaetanus minispinus, new species

6. Chirundina streetsi Gresbrecht

7. * Chirundina indica Sewell

8. * Chirundinella magna (WolfEnden)

9. * Undeuchaeta magna TANAKA

10. Undeuchaeta plumosa (LuBBocK)

11. Wilsonidius alaskaensis, new genus and species Euchaetidae

12. Euchaeta species

Scolecithricidae

13. * Scottocalanus infrequens, new species

14. * Scottocalanus rotundatus TANAKA

15. Scottocalanus securifrons (T. ScotT)

1) Address: 60 Sangenchaya, Setagaya, Tokyo

Publ. Seto Mar. Biol. Lab., XVII (4), 253-278, 1969. (Article 13) 
16. Lophothrix frontalis Giesbrecht

17. Scaphocalanus magnus (T. Sсотт)

Undinula vulgaris, Undeuchaeta plumosa, Euchaeta species, and Scottocalanus securifrons were found in the collection from the Atlantic, but others were all sampled by the Albatross from the Pacific. The species indicated by an asterisk are, however, not listed in the Albatross report.

This paper deals with the taxonomy of these copepods. Besides descriptions of the new species, systematic or distributional remarks are presented for each species. Euchaeta species was not examined thoroughly because of its immaturity. All specimens have returned to the U.S. National Museum.

I would like to express my sincere appreciation to Dr. Thomas E, Bowman of the U.S. National Museum for making this material available for me.

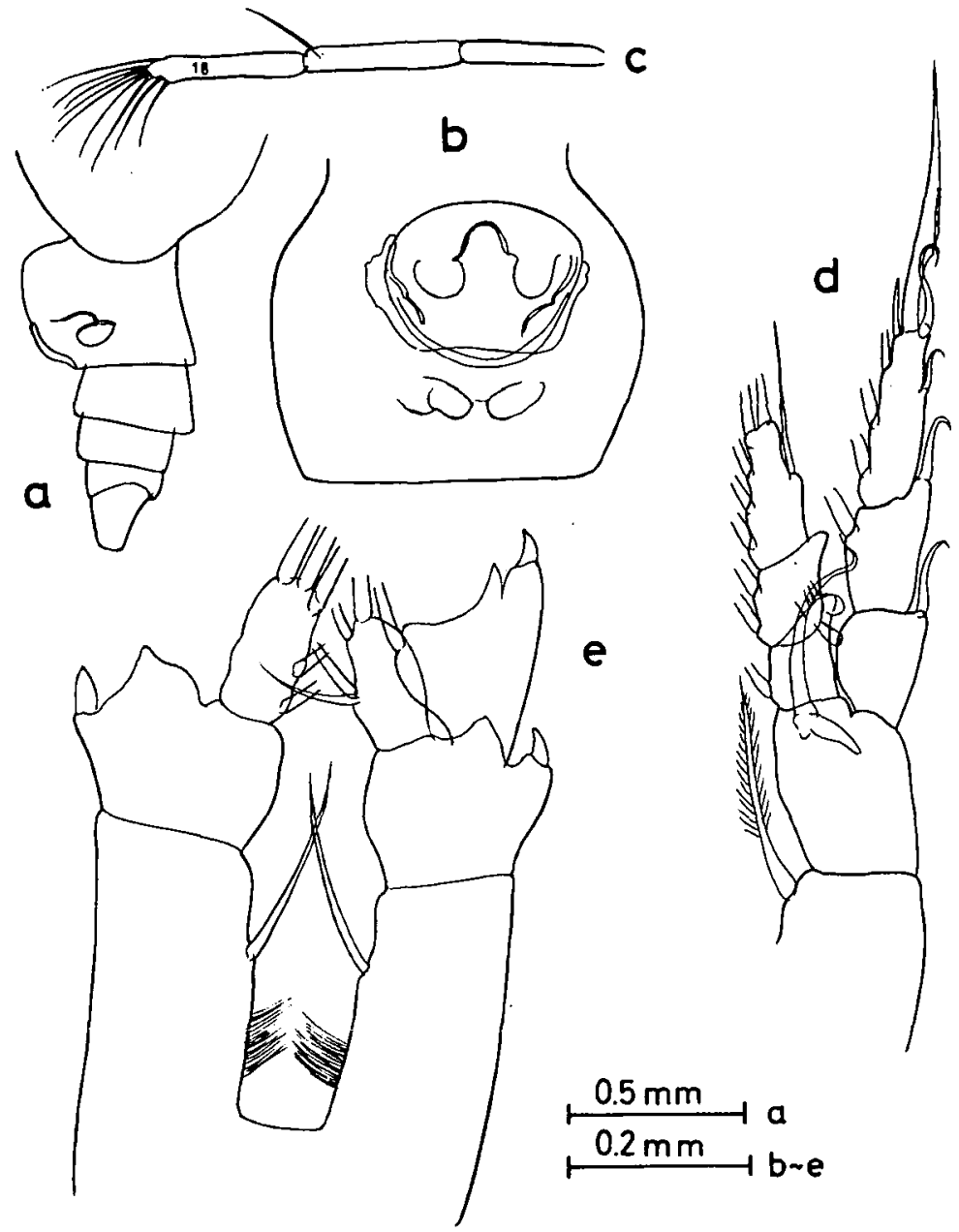

Fig. 1. Neocalanus robustior (GiesBrechT), female: a, abdomen lateral view; $b$, genital segment, ventral view; c, lst antenna; d, lst leg; e, 4th leg. 


\section{Neocalanus robustior (GIESBRECHT 1888)}

(Fig. 1, a-e)

Calanus robustior, GresBrecht, 1892, p. 91, pl. 7, figs. 15, 19, 25, 30, pl. 8, 34.

Neocalanus robustior, VeŔVOoRT, 1946, p. 44; VeRVOORT, 1963, p. 83

Occurrence: USNM No. 122533, Albatross Sta: 4680,1 ad. $q$.

Remarks: Female, $4.65 \mathrm{~mm}$. The genital segment is swollen; there is a ridge-like structure behind the genital opening. The 1 st and 2 nd legs are very characteristic in structure. In the present specimen the lst antenna is abnormal in that the 18th segment is regenerated, carrying 9 setae at the distal margin. The 4 th leg also has an abnormal endopod, 1-jointed instead of 3-jointed.

The occurrence of the species is well known in warm waters of the Atlantic and Indo-Pacific. The distribution and size variation are shown in the following table:

Author

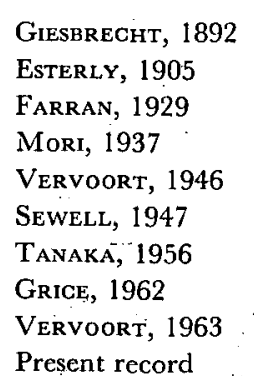

Locality

Atlantic and Pacific San Diego region Atlantic East China Sea Malay Archipelago Arabian Sea Sagami Bay Equatorial Pacific Gulf of Guinea Off Perú
Depth

\begin{tabular}{|c|c|}
\hline$-\because$ & $\begin{array}{c}9 \\
3.65-4.0\end{array}$ \\
\hline - & 3.17 \\
\hline Surface- & $4.05-4.32$ \\
\hline $0-30 \mathrm{~m}$ & $3.14-4.00$ \\
\hline $0-30 \mathrm{~m}$ & $3.55-3.80$ \\
\hline $0-500 \mathrm{~m}$ & $3.67-3.93$ \\
\hline Surface & - \\
\hline $62-126 \mathrm{~m}$ & $3.40-4.08$ \\
\hline $0-10 \mathrm{~m}$ & $3.42-3.90$ \\
\hline Surface & 4.65 \\
\hline
\end{tabular}

\section{Undinula vulgaris (DANA, 1849)}

Calanus vulgaris, Giesbrecht, 1892, p. 92, pl-6, fig. 11, pl. 7, figs. 2, 24, 27, 28, pl. 8, figs. 13, $17,35$. Undinula vulgaris, Sewelt, 1929, p..31, figs. 5-10; Vervoort, 1946, p. 72, fig. 6; Vervoort, 1963, p. 83.

Occurrence: USNM No. 122539, Carnegie Sta. 1, 1 ad. 우.

Remarks: Female, $2.83 \mathrm{~mm}$. This species is a surface inhabitant, and is found mainly in coastal waters. Its synonymy and distribution have been discussed by VERvoorT (1946). Some records of the distribution and size variation are given in the following table:

\section{Author}

SeWEll, 1929

WILSON, 1932

FARRAN, 1936

MORI, 1937
Locality

Bay of Bengal

Woods Hole region

Barrier Reef

East China Sea
Depth

Surface
$0-30 \mathrm{~m}$
$0-20 \mathrm{~m}$

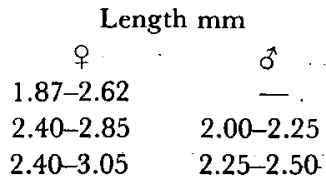




$\begin{array}{lllll}\text { VERvoORT, 1946 } & \text { Malay Archipelago } & \text { Surface } & 2.25-3.25 & 2.08-2.50 \\ \text { TANAKA, 1956 } & \text { Sagami Bay } & \text { Surface } & 2.75-2.81 & 2.31-2.69 \\ \text { Vervoort, 1963 } & \text { Gulf of Guinea } & \text { Surface } & 2.10-2.80 & 2.13-2.48 \\ \text { Present record } & \text { East of Maryland } & \text { Surface } & 2.83 & \end{array}$

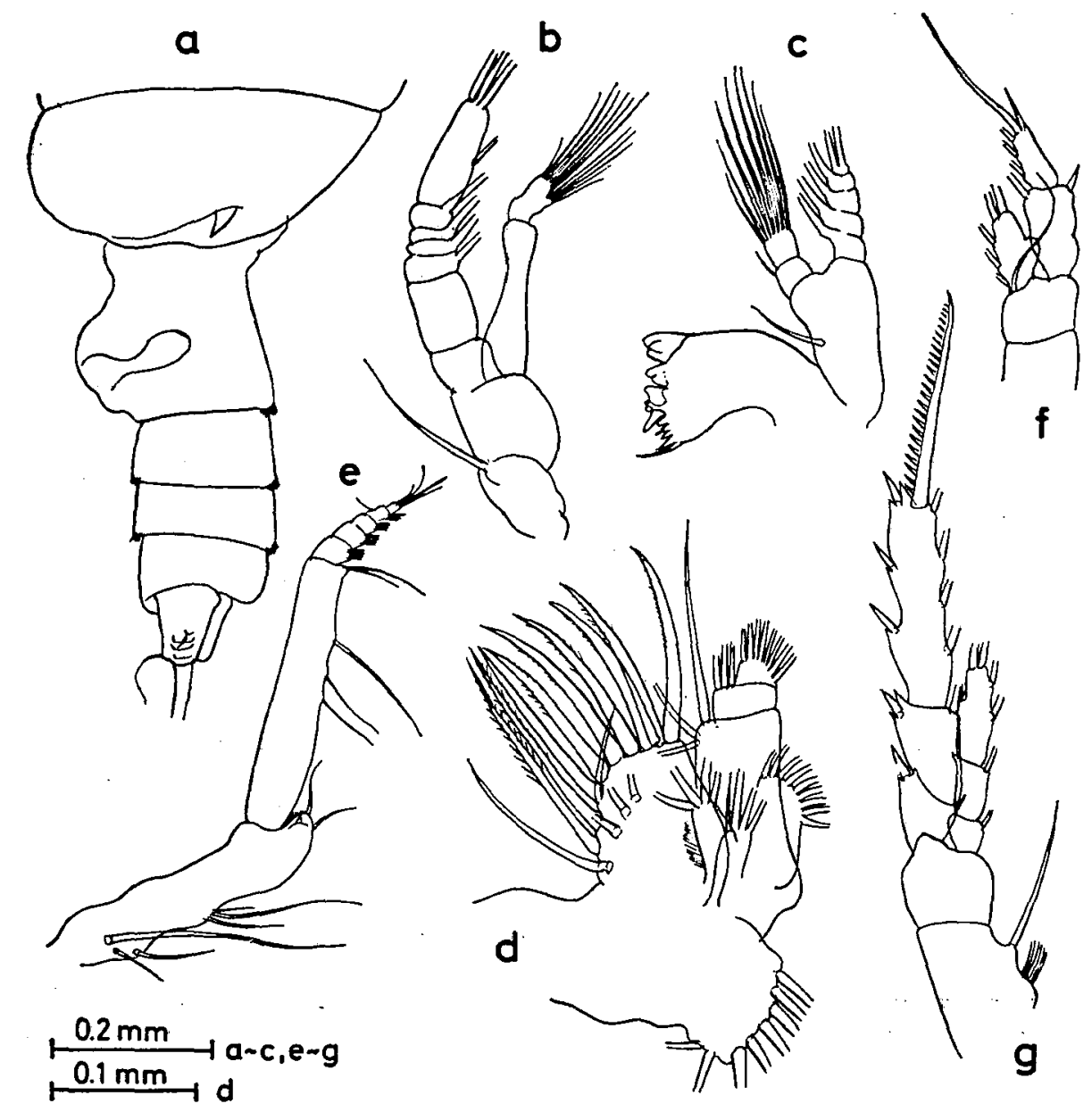

Fig. 2. Gaidius species, female: a, last thoracic segment and abdomen, lateral view; b, 2nd antenna; c, mandible; d, lst maxilla; e, maxilliped; f, lst leg; g, 4th leg.

\section{Gaidius species}

(Fig. 2, a-g)

Occurrence: USNM No. 70318, Albatross Sta. 4679, 1 ad. + .

Descriptive Notes: The specimen is very softened and mutilated in the cephalothorax. The abdomen is 4-jointed, measuring $0.52 \mathrm{~mm}$ in length. The abdominal segments and furca are in the following proportional lengths: 
Segment

\begin{tabular}{rrrrl}
$1-2$ & 3 & 4 & 5 & Furca \\
\hline 37 & 19 & 14 & 12 & $18=100$
\end{tabular}

The furcal ramus is longer than wide $(9: 6)$.

The 1st antenna is 24-jointed, measuring $2.8 \mathrm{~mm}$ in length. The segments are in the following proportional lengths:

\begin{tabular}{lrrrrrrrrrrrrrr} 
Segment & 1 & 2 & 3 & 4 & 5 & 6 & 7 & $8-9$ & 10 & 11 & 12 & 13 & 14 & 15 \\
\cline { 2 - 9 } & 101 & 54 & 29 & 25 & 29 & 25 & 29 & 39 & 22 & 25 & 22 & 39 & 39 & 39
\end{tabular}

\begin{tabular}{llllllllll}
16 & 17 & 18 & 19 & 20 & 21 & 22 & 23 & 24 & 25 \\
\hline 47 & 50 & 47 & 61 & 54 & 47 & 54 & 50 & 54 & 18
\end{tabular}$=1000$

The 2nd antenna has a 7-jointed exopod, and is about 1.5 times as long as the endopod. The endopod is slender, having 6 setae on the outer and inner lobes respectively. In the mandible the palp is slender; the endopod has 8 setae on the distal margin; the cutting edge has the usual structure. The 1st maxilla has the following number of setae on the various lobes: 8 setae on the outer lobe; 10 setae on the exopod; $8+3$ setae on the endopod; 3 setae on the 2nd basal segment; 4 setae on the 2nd and 3rd inner lobes respectively; 14 setae on the 1 st inner lobe. In the 2nd maxilla the spine on the 4 th inner lobe is very strong; the endopod has 6 setae. The maxilliped is slender; the lst basal segment has no lamellous plate on the outer margin.

In the 1 st leg the 1 st and 2 nd segments of the exopod are fused; there is no marginal spine on the 1st segment of the exopod. The 2nd leg has a 3-jointed exopod and a 1-jointed endopod; the terminal spine of the exopod has 19 teeth on the outer margin. The 3rd and 4th legs both have 3-jointed exopods and endopods; the terminal spine of the exopod has 17 teeth in the 3rd leg, and 23 teeth in the 4th leg respectively. The 1 st basal segment of the 4 th leg has 6 bristles on the inner margin.

Remarks: It is certain that the specimen is a member of the genus Gaidius. However, except $G$. minutus SARs, all species hitherto been described are larger than the present specimen. The specimen may be a new one, but it is better to leave it unnamed in view of the poor condition.

\section{? Gaetanus armiger GIESBRECHT, 1888}

(Fig. 3, a-e)

Gaetanus armiger Giesbrecht, 1892, p. 219, pl. 14, figs. 19, 20, 22, 23, 26, 28, 29, pl. 36, figs. 2, 4, 5; A. Scott, 1909, p. 45, pl. 8, figs. 16-22; MoRi, 1937, p. 40, pl. 17, figs. 8-13; TANakA, 1957, p. 172, . figs. 42 , a-d.

Occurrence: USNM No. 122749, Albatross Sta. 4679, 1 ad. $\delta$.

Descriptive Notes: Male, $2.55 \mathrm{~mm}$. The specimen is slightly deformed in the 
abdomen. The general appearance resembles that of G. kruppi Giesbrecht. The cephalothorax and abdomen are in the proportional lengths of 75 to 25 . The last thoracic segment is provided with a small rounded process on the ventral distal margin.

The abdominal segments and furca are in the following proportional lengths:

$\begin{array}{lllllll}\text { Segment } & 1 & 2 & 3 & 4 & 5 & \text { Furca }\end{array}$

$$
\begin{array}{llllll}
28 & 25 & 17 & 17 & 3 & 10=100
\end{array}
$$

The 2nd to 4th segments are fringed with spinules on the ventral distal margin.

The 1st antenna is 20-jointed, extending to the distal margin of the genital segment. The segments are in the following proportional lengths:

\begin{tabular}{|c|c|c|c|c|c|c|c|c|c|c|c|c|c|c|}
\hline \multicolumn{3}{|c|}{ Segment } & 1 & 2 & 3 & 4 & 5 & 6 & 7 & $8-9-10$ & 11 & $12-13$ & 14 & 15 \\
\hline \multicolumn{3}{|c|}{ Right } & 73 & 46 & 28 & 18 & 23 & 18 & 28 & 64 & 11 & 50 & 33 & 37 \\
\hline \multicolumn{3}{|c|}{ Left } & 75 & 49 & 31 & 22 & 22 & 22 & 27 & 67 & 32 & 44 & 35 & 31 \\
\hline 16 & 17 & 18 & 19 & $20-$ & & 22 & 23 & $24-2$ & & & & & & \\
\hline 41 & 41 & 50 & 60 & 110 & & 87 & 83 & $87=$ & 000 & & & & & \\
\hline 40 & 44 & 48 & 62 & 10 & & 89 & 84 & $80=$ & 000 & & & & & \\
\hline
\end{tabular}

The 2nd antenna has the exopod 1.4 times as long as the endopod. The endopod has 6 setae on the outer and inner lobes respectively. The lst maxilla has 7 setae on the outer lobe; 10 setae on the exopod; $7+3$ setae on the endopod including the 2 nd basal segment; the 1 st to 3 rd inner lobes are much reduced. The maxilliped is slender; there is no lamellous process on the outer margin of the 1st basal segment.

The 1st leg has a 3-jointed exopod and a 1-jointed endopod. The outer marginal spine of the 1st segment of the exopod is very small; the outer marginal spine of the 2 nd segment is replaced by a small blunt process accompanied by 2 small spines. The 2nd leg has a 3 -jointed exopod and a 2 -jointed endopod. The 3 rd and 4 th legs both have 3 -jointed exopods and endopods.

In the 5th pair of legs the 3rd segment of the exopod of the left leg is furnished with spinules on the inner margin near the proximal margin; the 2nd segment has a process furnished with spinules on the distal margin; the endopod of the left leg is small. The right leg has a 3 -jointed exopod and a 1-jointed endopod.

Remarks: The specimen comes near to G. kruppi or G. armiger in the structure of the forehead, the exopod of the 1 st leg, and the 1st segment of the maxilliped. It is also closely allied to G. simplex Brodsky, but in G. smiplex the 1st leg has a 2-jointed exopod. The endopod of the left 5 th leg is much longer proportionally than that of the present specimen. The distribution and size variation of $G$. armiger are as follows:

Author Locality Depth Length $\mathrm{mm}$

$\begin{array}{llccc} & & q & \delta \\ \text { A. ScoTt, 1909 } & \text { Malay Archipelago } & 0-900 \mathrm{~m} & 3.5 & - \\ \text { SARs, } 1925 & \text { North Atlantic } & 0-2000 \mathrm{~m} & 3.0 & -\end{array}$


Tanaka, 1957

Sagami Bay

$0-1000 \mathrm{~m} \quad 3.37$

Present record

Gulf of Guinea

0. $600 \mathrm{~m} \quad 2.95-3.05$

-

Peru to Easter Is.

$0-300 \mathrm{fms} \quad-$

2.55
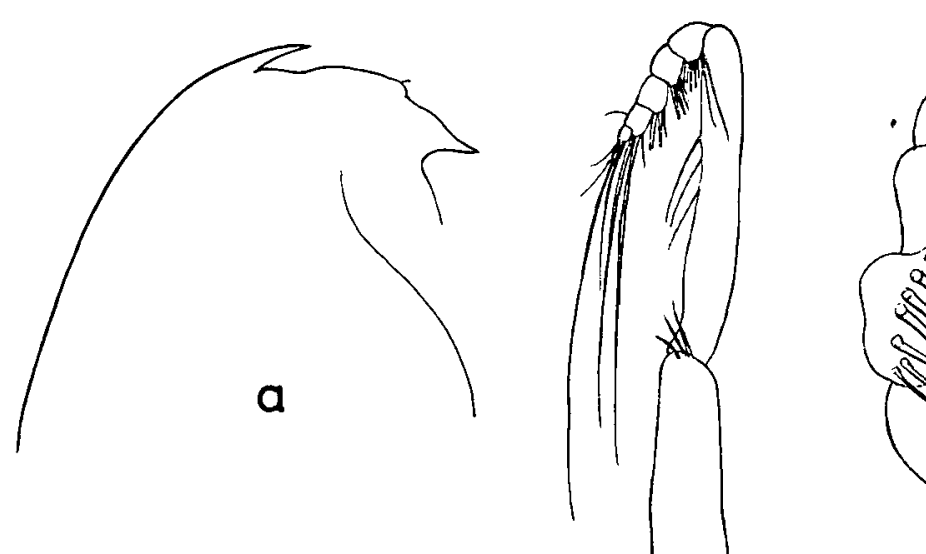

2.55

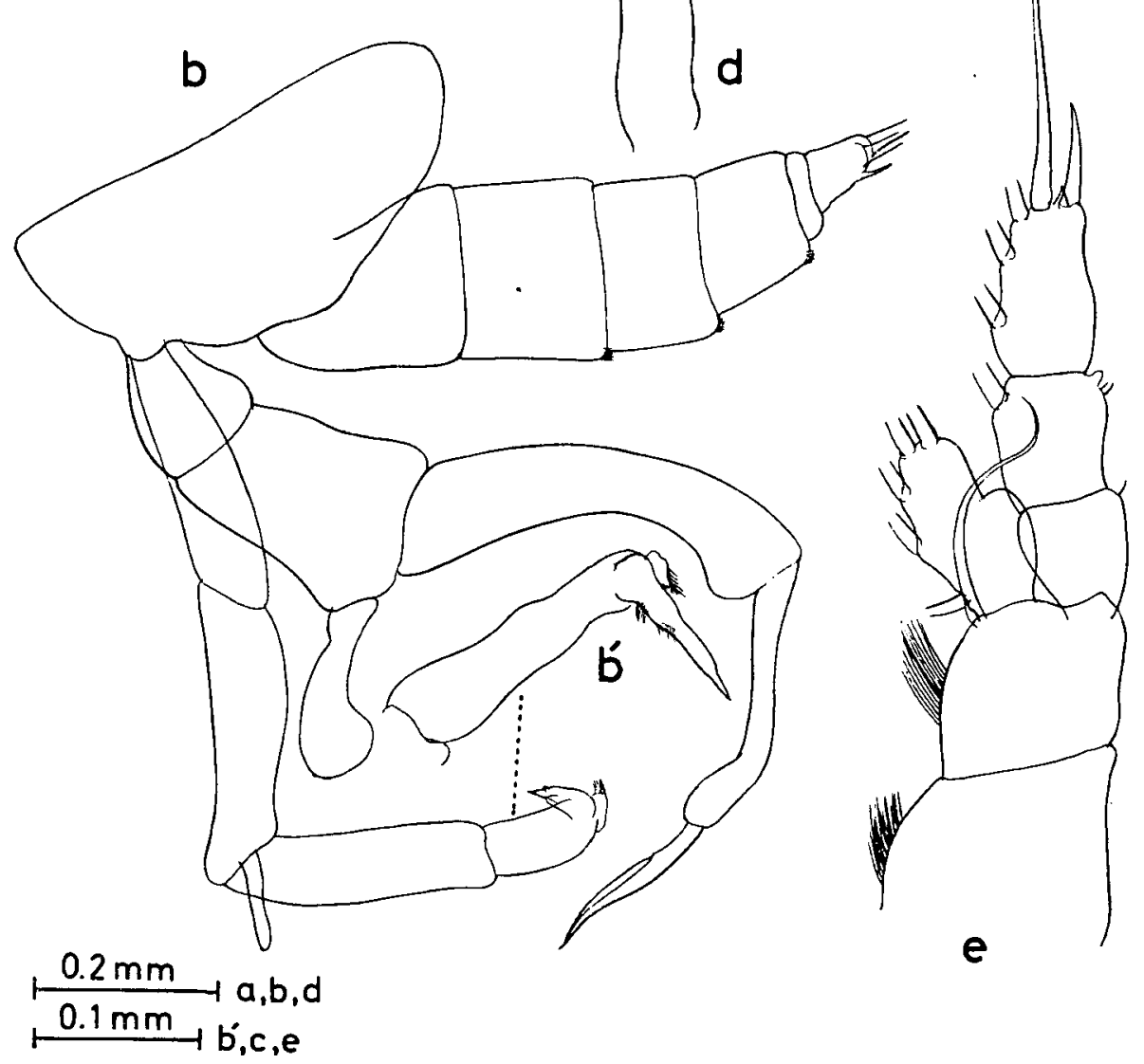

Fig. 3. ?Gaetanus armiger Giesbreahr, male: a, head, lateral view; b, last thoracic segment, abdomen and 5 th pair of legs; c, lst maxilla; d, maxilliped; e, Ist leg. 


\section{Gaetanus minispinus, new species}

(Fig. 4, a-h)

Occurrence: USNM No. 122750, Albatross Sta. 5320, 1 ad. ㅇ.

Descriptive Notes: Female, $5.50 \mathrm{~mm}$ (holotype, USNM No. 122750). The body is

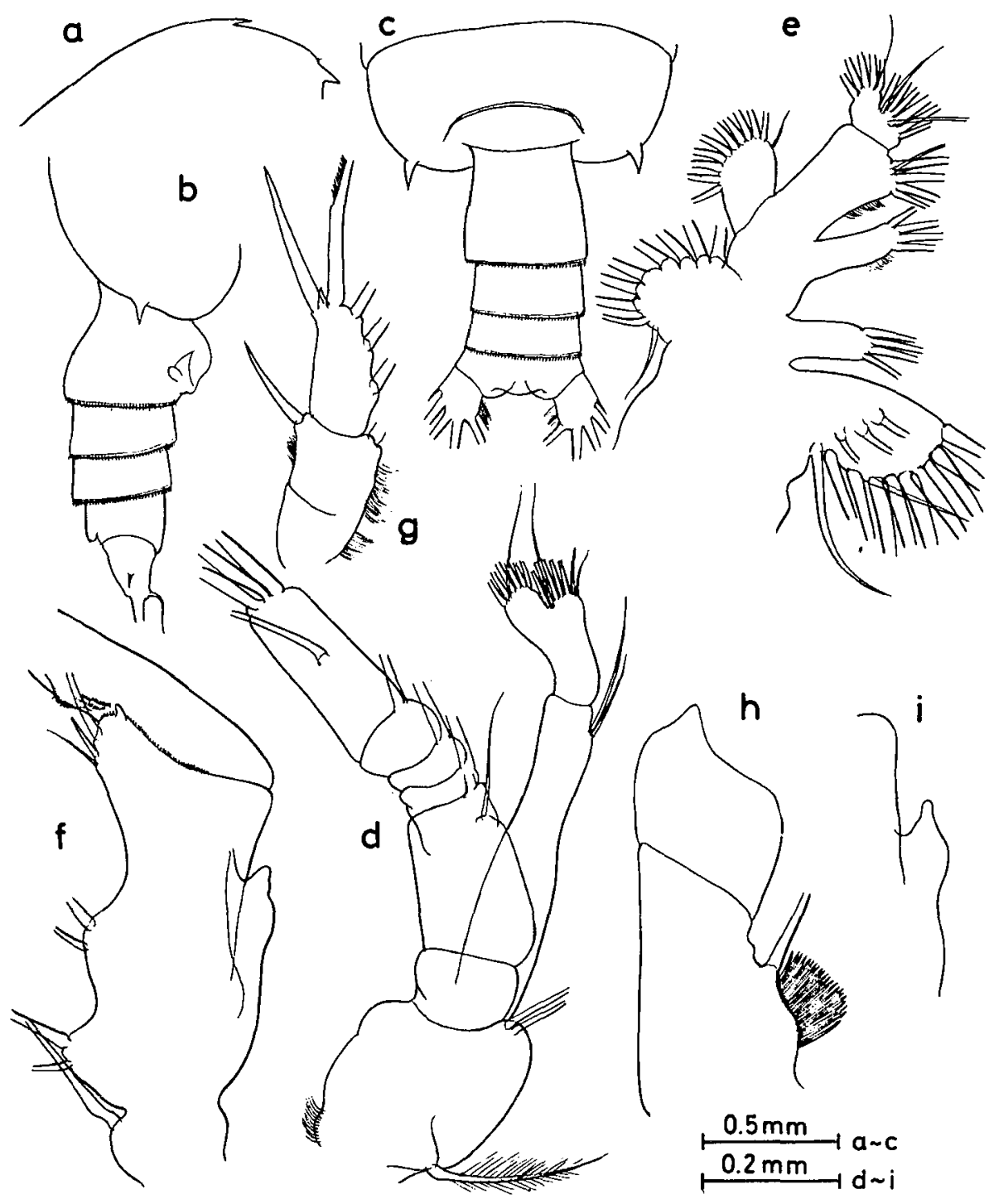

Fig. 4. Gaetanus minispinus, new species, female: $a$, head, lateral view; $b$, last thoracic segment and abdomen, lateral view; c, last thoracic segment and abdomen, dorsal view; d, 2nd antenna; e, lst maxilla; f, maxilliped; g, lst leg, exopod; h, 4th leg. Gaetanus kruppi Giesbrecht, female: i, maxilliped, lamellous process of lst basal segment. 
robust. The cephalothorax and abdomen are in the proportional lengths of 78 to 22 . The head is fused with the 1 st thoracic segment; the 4 th and 5 th thoracic segments are fused. The cephalic spine is very small. The last thoracic segment is furnished with a small lateral spine on the distal margin. The rostrum is directed ventrally.

The abdominal segments and furca are in the following proportional lengths:

\begin{tabular}{llllll} 
Segment & $1-2$ & 3 & 4 & 5 & Furca \\
\cline { 2 - 5 } & 38 & 17 & 16 & 10 & $19=100$
\end{tabular}

The genital segment is symmetrical, swollen below; the distal margin of the segment is striated with spinules. The $3 \mathrm{rd}$ and 4 th segments are striated with spinules on the distal margin. The furcal ramus is as long as wide.

The 1st antenna extends beyond the end of the furca by the distal 2 segments; it measures $6.3 \mathrm{~mm}$ in length; the segments are in the following proportional lengths:

$\begin{array}{lllllllllllllllll}\text { Segment } & & \frac{1}{2} & 2 & 3 & 4 & 5 & 6 & 7 & 8-9 & 10 & 11 & 12 & 13 & 14 & 15 \\ & & & 59 & 49 & 27 & 25 & 25 & 29 & 33 & 53 & 24 & 27 & 27 & 51 & 29 & 49 \\ 16 & 17 & 18 & 19 & 20 & 21 & 22 & 23 & 24 & 25 & & & & & & \\ 49 & 53 & 48 & 60 & 55 & 40 & 59 & 51 & 38 & 19=1000 & & & \end{array}$

In the 2nd antenna the exopod is about as long as the endopod; the endopod has 8 setae on the inner lobe, and 7 setae on the outer lobe. The mandible has 9 setae on the distal margin of the endopod; the cutting edge is furnished with 8 teeth and an inner marginal seta. The lst maxilla has the following number of setae on the various lobes : 9 setae on the outer lobe; 11 setae on the exopod; $4+4+6$ setae on the endopod; 5 setae on the 2 nd basal segment; 4 setae on the 3 rd inner lobe; 4 setae on the 2 nd inner lobe; 14 setae on the 1 st inner lobe. The 2 nd maxilla is robust; the proximal outer margin of the 1st basal segment is swollen; the endopod has 6 setae; the 5 th inner lobe is furnished with 2 spines on the anterior distal margin. In the maxilliped the 1st basal segment is furnished with a lamellous process on the outer margin which differs in shape from that of G. kruppi (Fig. 4, i).

The 1st leg has a 2-jointed exopod and a 1-jointed endopod; the 1st and 2nd segments of the exopod are incompletely fused; the outer marginal spine of the 2nd segment is long, reaching the distal margin of the 3rd segment of the exopod. The 2nd leg has a 3-jointed exopod and a 2-jointed endopod; the terminal spine of the exopod has 21 teeth. The 3rd and 4th legs have 3-jointed exopods and endopods. In the 4th leg the 1st basal segment is furnished with about 23 bristles on the inner margin.

Remarks: The present species is closely allied to G. kruppi Giesbrecht and also to $G$. simplex BRODsky. However, it is distinguished from them by the small cephalic spine, small lateral spines on the last thoracic segment, and the shape of the lamellous process on the lst basal segment of the maxilliped. The outer marginal spine of the 
2nd segment of the exopod of the lst leg is also characteristic.

The present species occurs in the Izu region, too.

\begin{tabular}{lllll}
\multicolumn{1}{c}{ Author } & \multicolumn{1}{c}{ Locality } & Depth & \multicolumn{2}{c}{ Length $\mathrm{mm}$} \\
$\begin{array}{l}\text { TANAKA \& OMorI } \\
\text { (unpublished) }\end{array}$ & Izu region & $0-680 \mathrm{~m}$ & $5.15-5.56$ & $\delta$ \\
Present record & China Sea & $0-500 \mathrm{fms}$ & 5.50 & -
\end{tabular}

\section{Chirundina streetsi GIESBRECHT, 1895}

Chirundina streetsi, Esterly, 1906, p. 59, pl. 9, fig. 2, pl. 10, fig. 28, pl. 12, fig. 58, pl. 14, figs. 86, 87; A. Scotr, 1909, p. 43, pl. 12, figs. 1-11; SARs, 1925, p. 77, pl. 22 figs. 8-13; TANAKA, 1957, p. 190, fig. 53; GRICE, 1962, p. 196, figs. $1-4$.

Occurrence: USNM No. 122505, Albatross Sta. 5320, 1 ad. O; USNM No. 122506, Bache Sta. 10210, 3 ad. $\delta$ and 1 ad. $\delta$.

Remarks: Female, $4.45-5.30 \mathrm{~mm}$; male $4.50 \mathrm{~mm}$. This is very widely distributed over deep waters of the Atlantic, Indian, and Pacific Oceans.

Author

A. Scotт, 1909

WITH, 1915

SARS, 1925

FARRAN, 1929

SEWEll, 1947

Brodsky, 1950

TANAKa, 1957

GRICE, 1962

VERVOORT, 1963

Present record
Locality

Malay Archipelago

North Atlantic

Atlantic

Off New Zealand

Arabian Sea

Far eastern seas of the USSR

Izu region

Equatorial Pacific

Gulf of Guinea

China Sea and off

Bahamas
Depth

$$
\text { 0-2000 m }
$$$$
0-600 \mathrm{~m}
$$$$
0-1500 \mathrm{~m}
$$$$
\text { Surface }
$$$$
\text { 0-1500 m }
$$$$
-
$$

$0-1000 \mathrm{~m}$

$0-280$

$100-600 \mathrm{~m}$

$0-500 \mathrm{fms}$
Length mm क
$4.80-5.30$

$$
5.22
$$

5.10

4.15

5.35

$$
5.0-5.1
$$

5.01

4.94

$4.65-5.55$

$4.45-5.30$

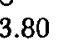

3.80

4.20
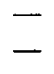

$4.3-4.5$

4.81

$4.05-4.80$

4.50

\section{Chirundina indica Sewell, 1929}

(Fig. 5, a-e)

Chirundina indica Sewell, 1929, p. 119, figs. 45, 46; Sewell, 1947, p. 92, fig. 20; Grice, 1962, p. 196, pl. 11, figs. 5-20.

Occurrence: USNM No. 122504, Albatross Sta. 5231, 1 ad. $\hat{0}$.

Descriptive Notes: Male, $3.75 \mathrm{~mm}$. The present specimen agrees fairly well with the description of C. indica given by SEWELL (1947). The lst antenna extends to the distal margin of the furca. The 2nd antenna has the exopod about 1.5 times as long as the endopod; the endopod has 6 setae on the outer lobe, and 7 setae on the inner lobe. The mandible is of the usual structure, and has 9 setae on the endopod, and 6 
setae on the exopod. In the 1 st maxilla the outer lobe has 5 setae; the exopod has 11 setae; the endopod has 8 setae; the 2 nd basal segment has 3 setae; the 3rd inner lobe has 1 seta; the lst and 2nd inner lobes are much reduced.

The 1st leg has a 3-jointed exopod and a 1-jointed endopod; there is no marginal

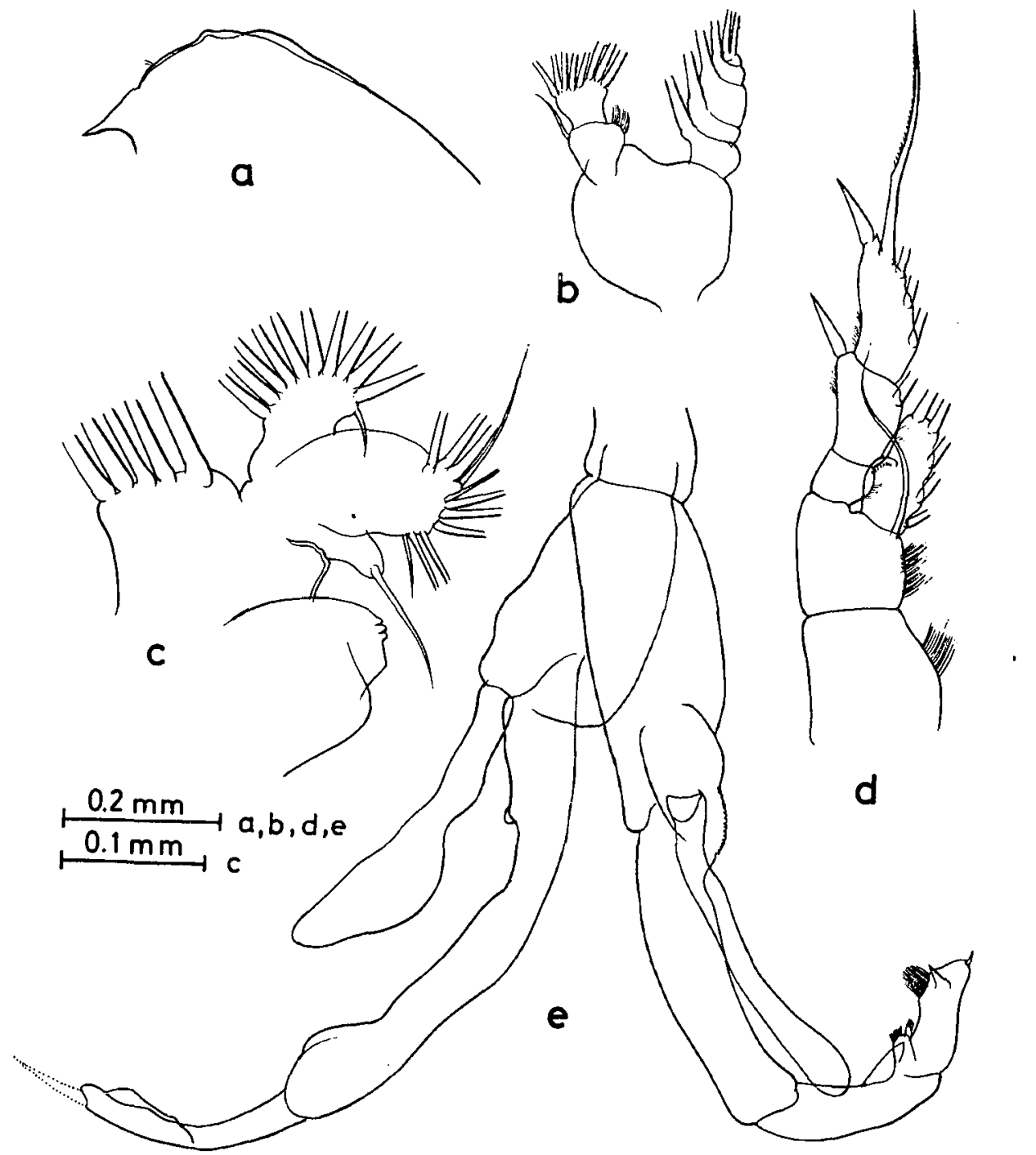

Fig. 5. Chirundina indica Sewell, male: a, head, lateral view; b, mandible; c, 1st maxilla; d, 1st leg; e, 5th pair of legs.

spine on the Ist segment of the exopod. The 5th pair of legs agrees well with that figured by SEWELL.

Remarks: According to Sewell (1947), the 2nd antenna of the male has 8 setae on 
the inner and outer lobes respectively. In the present specimen, however, the inner lobe has 7 setae, and the outer lobe has 6 setae. An inner marginal seta might have been lost in the present specimen. The 1st maxilla has 11 setae on the exopod and 11 setae on the endopod including the 2 nd basal segment in the present specimen, whereas, it has 10 and 10 setae respectively in SEwELL's one.

Author Locality Depth Length $\mathrm{mm}$

\begin{tabular}{llllr} 
& & \multicolumn{1}{c}{} & $\delta$ \\
SEWELL, 1929 & Arabian Sea & $0-200 \mathrm{fms}$ & $4.19-4.75$ & - \\
SEWELL, 1947 & Arabian Sea & $0-300 \mathrm{~m}$ & $4.05-5.00$ & 3.97 \\
Grice, 1962 & Equatorial Pacific & $0-169 \mathrm{~m}$ & 4.66 & - \\
Present record & Off Philippines & $0-80 \mathrm{fms}$ & - & 3.75
\end{tabular}

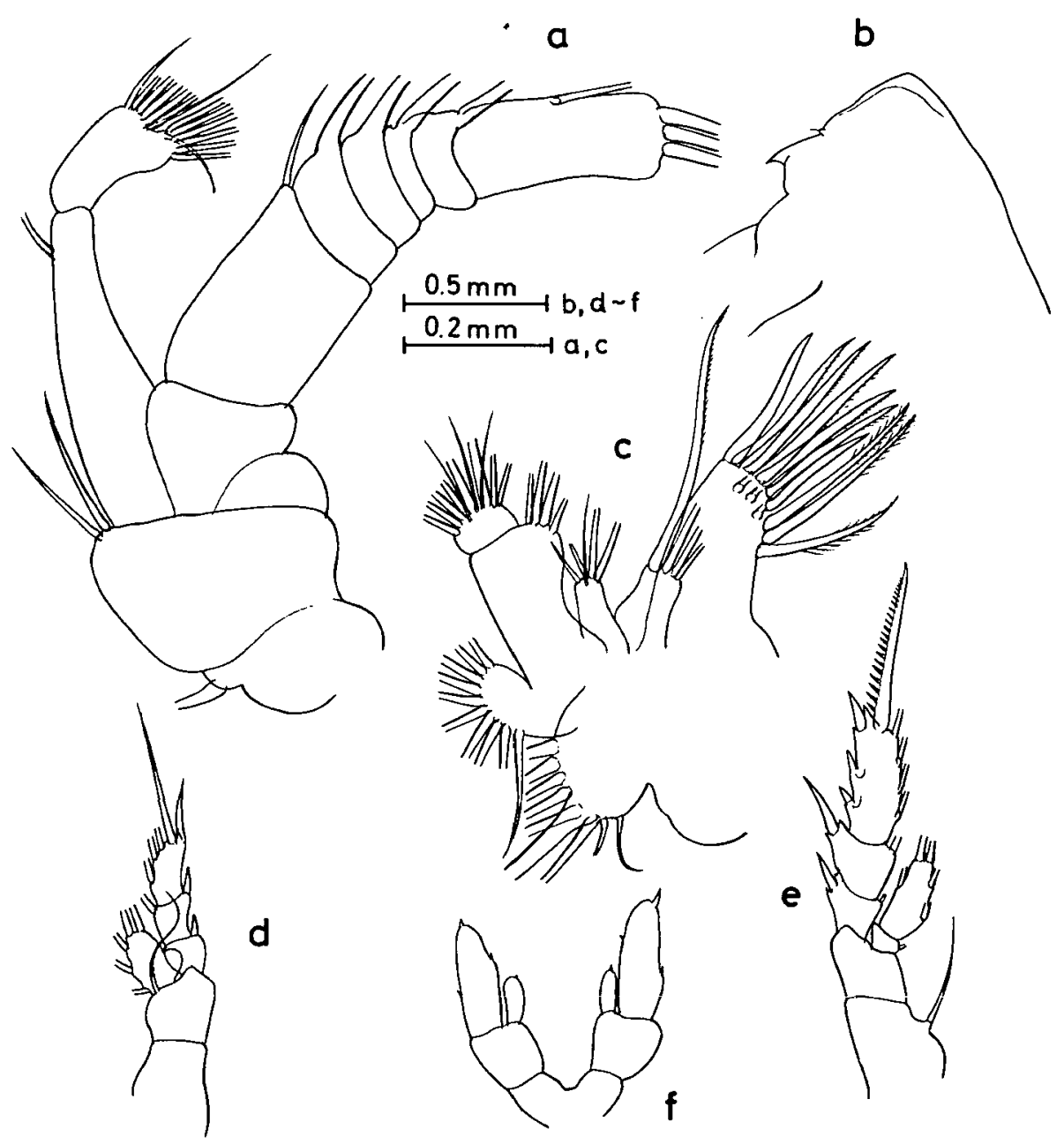

Fig. 6. Chirundinella magna (Wolfenden), female: a, 2nd antenna. Immature male: b, head, lateral view; c, 1st maxilla; d, 1st leg; e, 2nd leg; f, 5th pair of legs. 


\section{Chirundinella magna (WoLfENDEN, 1911)}

(Fig. 6, a-f)

Chirundina magna Wolfenden, 1911, p. 241, text-fig. 27, a, b, pl. 28, figs. 10-13.

Chirundinella cara Tanaka, 1957, p. 197, fig. 57; Grice \& Hulsemann, 1967, p. 23, fig. 55.

Occurrence: USNM No. 122503, Albatross Sta. 4652, 1 ad. \&; USNM No. 70314, Albatross Sta. 4680,1 juv. ơ.

Remarks: The present genus is very closely allied to Chirundina but is easily distinguished from the latter by having a long appendicular seta on the furcal rami, the structure of the 1st maxilla, and by the absence of the marginal spine on the 1st segment of the 1st leg. C. magna WoLfENDEN (1911) may be a synonym of the present species. His specimens measured $6.0-6.6 \mathrm{~mm}$ in length.

The immature male measured $6.9 \mathrm{~mm}$ in length and has a 4-jointed abdomen. The 2 nd antenna has 5 setae on the outer lobe and 7 setae on the inner lobe. In the lst maxilla the outer lobe has 9 setae, of which the proximal 4 are very strong; the endopod has 11 setae; the 2 nd basal segment has 4 setae; the 3rd inner lobe has 5 setae; the 2nd inner lobe has 4 setae; the 1 st inner lobe has 13 setae. The 5 th pair of legs is undeveloped; the exopod and endopod are 1-jointed.

\begin{tabular}{llccc}
\multicolumn{1}{c}{ Author } & \multicolumn{1}{c}{ Locality } & Depth & \multicolumn{2}{c}{ Length mm } \\
& & $0-1000 \mathrm{~m}$ & 7.44 & - \\
TANAKA, 1957 & Sagami Bay & & & - \\
Grice \& & & $275-817 \mathrm{~m}$ & 7.80 & $0.9(\mathrm{~V}$ stage $)$ \\
HulsEMANn, 1962 & Arbian Sea & $0-400 \mathrm{fms}$ & 8.10 &
\end{tabular}

Undeuchaeta plumosa (LuBBOcK, 1856)

Undeuchaeta minor Giesbrecht, 1892, p. 228, pl. 14, figs. 31-34, pl. 37, figs. 55, 58.

Undeuchaeta plumosa, A. Scotr, 1909, p. 62, pl. 22, figs. 1-6; SARs, 1925, p. 79, pl. 23, figs. 1-6; MoRI, 1937, p. 41, pl. 17, figs. 6, 7; Vervoort 1957, p. 70; TANAKA, 1957, p. 199, fig. 58; Grice, 1962, p. 199, pl. 12, figs. 1-14.

Occurrence: USNM No. 122538, Bache Sta. 10210, 2 ad. 우.

Remarks: This is a common sub-surface species in warm waters in the Atlantic, Indian, and Pacific Oceans. Some records of its distribution and size variation are summarized in the following table:

Author

Locality

Gtesbrecht, 1892

A. Scotт, 1909

SARs, 1925

FARRAN, 1929

\section{Pacific}

Malay Archipelago

Atlantic

Atlantic and off New

Zealand
Depth

0-1500 m

0- $700 \mathrm{~m}$

Surface

Surface
Length mm

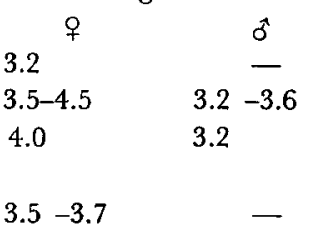




$\begin{array}{llcll}\text { MoRi, 1937 } & \text { East China Sea } & 0-100 \mathrm{~m} & 3.2 & 3.1 \\ \text { BRodSKY, 1950 } & \begin{array}{l}\text { Far eastern seas of } \\ \text { the USSR }\end{array} & - & 3.2-4.2 & 3.2 \\ \text { TANAKA, 1957 } & \text { Izu region } & 0-1000 \mathrm{~m} & 3.61 & 3.45 \\ \text { GRICE, 1962 } & \text { Equatorial Pacific } & 0-150 \mathrm{~m} & 3.41-3.47 & 3.52 \\ \text { VERVooRT, 1963 } & \text { Gulf of Guinea } & 0-10 \mathrm{~m} & 3.30-3.75 & 2.85-3.35 \\ \text { Present record } & \text { Off Bahamas } & - & 3.60-3.80 & \end{array}$

Undeuchaeta magna TANAKA, 1957

(Fig. 7, a-e)

Undeuchaeta magna TANAKA, 1957, p. 203, fig. 60; PAIva, 1963, p. 39, fig. 17.

Occurrence: USNM No. 122537,1 ad. ㅇ.

Remarks: The present species resembles $U$. bispinosa EsTERLY, but can be distinguished from the latter by its larger size and by the armature of the genital segment of the female. The 2nd antenna has the exopod 1.8 times as long as the endopod; the endopod has 7 setae on the outer lobe, and 8 setae on the inner lobe. The mandible is of the usual structure. In the lst maxilla the outer lobe is furnished with 9 setae; the exopod with 11 setae; the endopod with 13 setae; the 2 nd basal segment with 4 long and 2 small setae; the 3 rd inner lobe with 4 setae; the 2 nd inner lobe with 3 setae, and the 1 st inner lobe with 14 setae The 2 nd maxilla is like that of $U$. bispinosa figured by SEWELL (1929). In the maxilliped the segments of the endopod are short and robust; the lst basal segment is half as long as the 2nd one.

In the 1 st leg the 1st and 2nd segments of the exopod are fused. In the present specimen the left leg is abnormal in structure; it is provided with an outer marginal spine on the area where the 1 st and 2 nd segments are fused. The right leg is normal, and is devoid of the spine on the same area. The 4th leg has bristles on the inner proximal margin of the 1st basal segment; the terminal spine of the exopod has about 40 teeth. The species has been reported from the Pacific and Atlantic.

\begin{tabular}{llccc}
\multicolumn{1}{c}{ Author } & \multicolumn{1}{c}{ Locality } & Depth & \multicolumn{2}{c}{ Length mm } \\
& & & 0 & $\delta$ \\
TANAKA, 1957 & Suruga Bay & $0-1000 \mathrm{~m}$ & 6.07 & - \\
PAIVA, 1963 & Off Cape Verde & - & 6.29 & - \\
Present record & Pacific & - & 6.03 &
\end{tabular}

\section{Wilsonidius, new genus}

Type Species: Wilsonidius alaskaensis

Definition: Cephalothorax elongate ovate. Head is fused with 1 st thoracic segment; 4 th and 5th thoracic segments are fused. Head has no median crest. Rostrum 1pointed. Abdomen 4-segmented in the female. Furcal ramus is furnished with a small lateral spine, 4 long setae, and an appendicular seta. First antenna 24-jointed; 
the 8 th and 9th segments are fused; the 24th and 25th are separated. The 2nd antenna has a 7-jointed exopod which is longer than the endopod. The mandibular palp is furnished with marginal setae; exopod is longer than endopod; the cutting edge has the normal structure. The 1 st maxilla has 9 setae on the outer lobe; endopod has 15 setae; 2 nd basal segment has 5 setae. The 2 nd maxilla as in Undeuchaeta. In

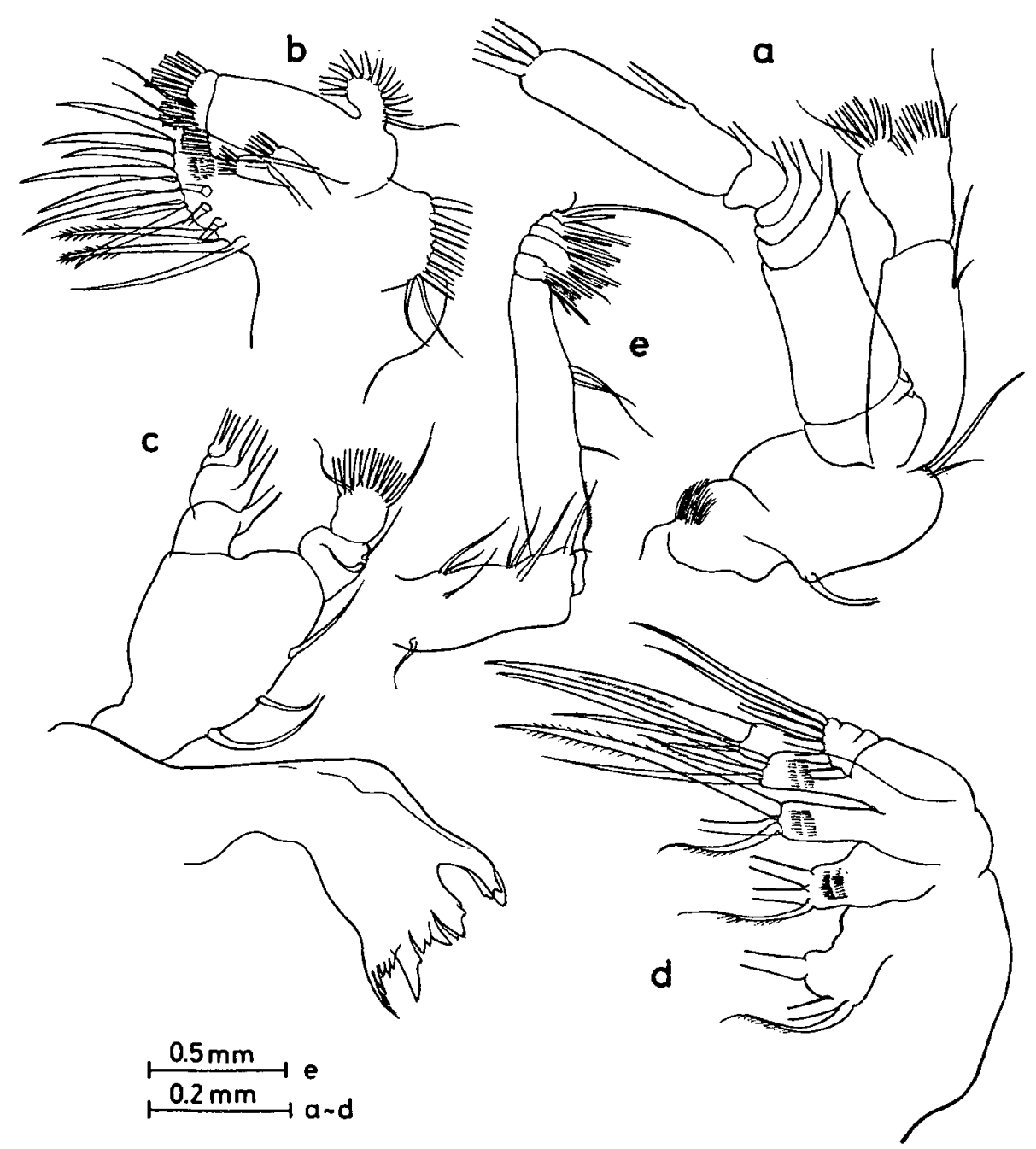

Fig. 7. Undeuchaeta magna TANAKA, female: a, 2nd antenna; b, 1st maxilla; c, mandible; d, 2nd maxilla; e, maxilliped.

the maxilliped the 2 nd basal segment is much longer than the 1 st one; the outer margin of the 2 nd basal segment is striated with a lamellous plate. The 1 st leg has a $3-$ jointed exopod and a 1-jointed endopod. The 2 nd leg has a 3 -jointed exopod and 
a 1-jointed endopod. The 3rd and 4th legs have 3-jointed exopods and endopods. The 4th leg has no spine on the inner margin of the 1st basal segment. The 5th leg is absent in the female. Male is unknown.

\section{Wilsonidius alaskaensis new species}

(Fig. 8, a-f and 9, a-f)

Occurrence: USNM No. 67133, Albatross Sta. 4750, 1 ad. ㅇ‥

Descriptive Notes: Female, $3.70 \mathrm{~mm}$ (holotype, USNM No. 67133). The body is elongate ovate, 3 times as long as wide. The cephalothorax and abdomen are in the proportional lengths of 74 to 26 . The head is fused with the 1st thoracic segment; the 4 th and 5th thoracic segments are fused. The frontal margin of the head is produced in dorsal view; however, it is broadly rounded in lateral view. The distal margin of the last thoracic segment is narrowly rounded but is irregular in outline at the apex. There is a demarcation between the 4th and 5th thoracic segments along the lateral margins, but no line of separation between these segments was observed. The rostrum is 1-pointed and long, directing downwards.

The abdominal segments and furca are in the following proportional lengths:

\begin{tabular}{lrrrll} 
Segment & $1-2$ & 3 & 4 & 5 & Furca \\
\cline { 2 - 5 } & 45 & 19 & 13 & 5 & $18=100$
\end{tabular}

The genital segment is symmetrical, and dilated posteriorly; it is swollen considerably below. The 3rd and 4th segments are fringed with fine spinules on the distal margin. The furcal ramus is as long as wide; it carries a small lateral spine, 4 long setae and an appendicular seta.

The 1st antenna is 24-jointed, extending to the end of the 3rd abdominal segment; it measures $4.3 \mathrm{~mm}$ in length. The segments are in the following proportional lengths:

\begin{tabular}{|c|c|c|c|c|c|c|c|c|c|c|c|c|c|c|c|}
\hline \multicolumn{3}{|c|}{ Segment } & 1 & 2 & 3 & 4 & 5 & 6 & 7 & $8-9$ & 10 & 11 & 12 & 13 & 14 \\
\hline & & & 69 & 51 & 25 & 30 & 30 & 28 & 30 & 46 & 25 & 30 & 30 & 39 & 41 \\
\hline 16 & 17 & 18 & 19 & 20 & 21 & 22 & 23 & 24 & 25 & & & & & & \\
\hline 51 & 55 & 48 & 67 & 58 & 44 & 48 & 51 & 41 & $12=$ & 1000 & & & & & \\
\hline
\end{tabular}

The 2nd antenna has a 7-jointed exopod which is about 1.5 times as long as the endopod; the 1st segment of the exopod is furnished with a small seta on the inner distal margin; the 2nd segment has 2 small setae on the inner proximal margin and a small one at the inner distal margin; the 3 rd to 6 th segments are furnished with a long seta respectively; the 7 th segment has 3 terminal and an inner marginal setae. The distal segment of the endopod carries 8 setae on the inner lobe, and 7 setae on the outer lobe.

The mandibular palp is elongate; it is furnished with 3 inner marginal setae; the 




Fig. 8. Wilsonidius alaskaensis, new genus and new species, female: a, whole animal, lateral view; $b$, head, dorsal view; c, last thoracic segment and abdomen, dorsal view; d, 1st antenna; e, 2nd antenna; $f$, mandible. 


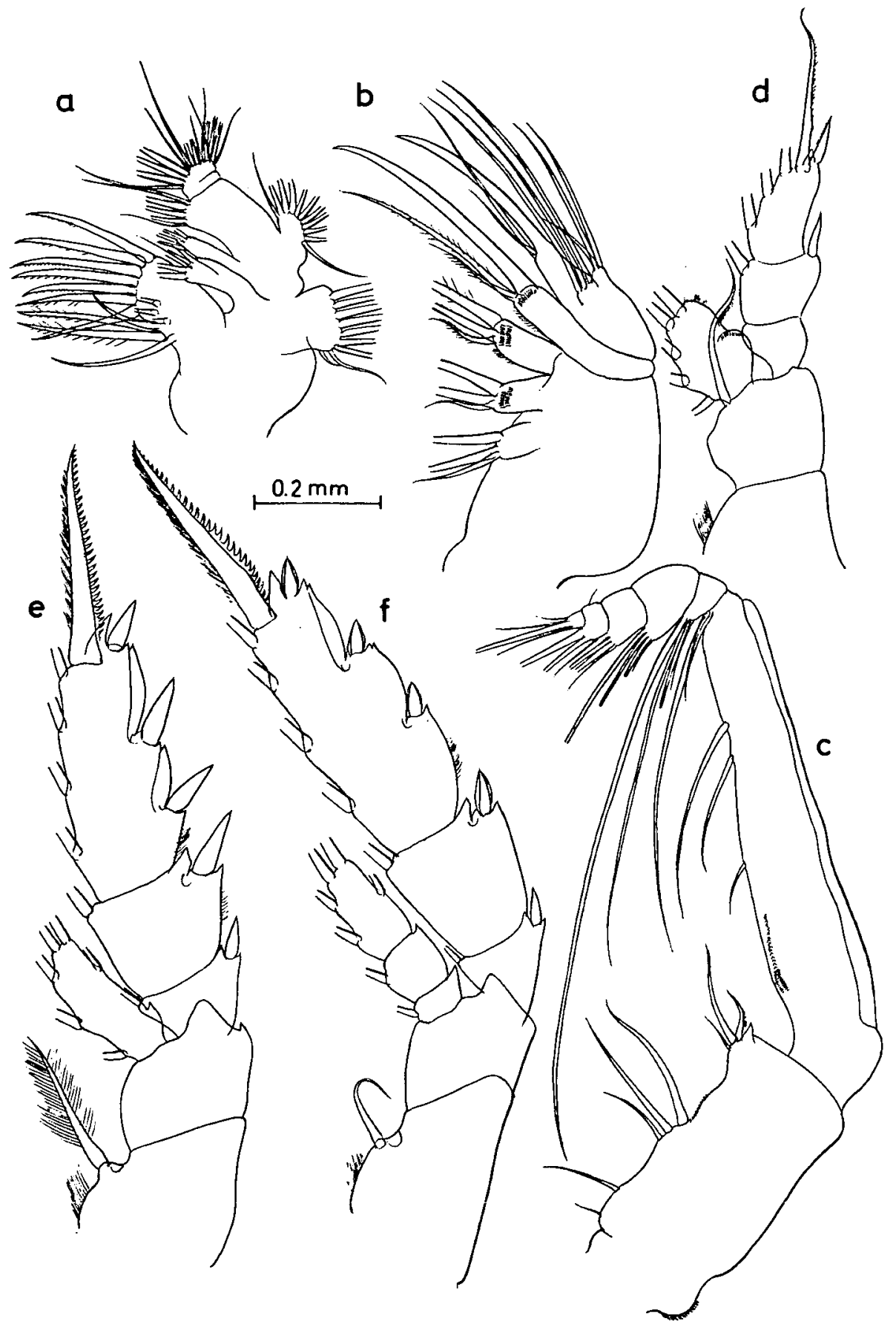

Fig. 9. Wilsonidius alaskaensis, new genus and new species, female: a, 1st maxilla; b, 2nd maxilla; c, maxilliped; d, lst leg; e, 2nd leg; f, 4th leg. 
exopod is 5-jointed, carrying 6 setae in all; the 1 st segment of the endopod is furnished with 2 marginal setae; the distal segment with 10 setae. The cutting blade has 8 teeth and an inner marginal seta.

The 1st maxilla has 9 setae on the outer lobe; 11 setae on the exopod; $6+5+4$ setae on the 3 rd to 1 st segments of the endopod; 5 setae on the 2 nd basal segment; 4 setae on the 3 rd inner lobe; 5 setae on the 2 nd inner lobe; 14 setae on the 1 st inner lobe.

The 2nd maxilla is like that of Euchirella or Gaidius. The 1st basal segment is swollen on the proximal outer margin; the 1st to 5 th inner lobes are furnished with 3 setae respectively; the endopod has 6 setae.

In the maxilliped the 2nd basal segment is 2 times as long as the 1st one, and is striated with a lamellous plate along the outer margin; in the endopod the segments are short and are furnished with $4,3,3,3+1$ and $3+1$ setae on the 1 st to 5 th segments.

The 1st leg has a 3-jointed exopod and a 1-jointed endopod; the 1st segment of the exopod is devoid of any marginal spine; the 2nd and 3rd segments have a marginal spine. The 2nd leg has a 3-jointed exopod and a 1-jointed endopod; the 3rd segment of the exopod has 3 marginal spines; the terminal spine has 37 teeth. The 3 rd leg is composed of 3-jointed exopod and endopod. The 4th leg has 3-jointed exopod and endopod; the lst basal segment has no spine on the inner margin; the terminal spine of the exopod has 29 teeth.

Remarks: The present specimen is closely related to those of the genus Undeuchaeta, but it is difficult to assign this species to any of the members of the genus. The present genus is distinguished from Undeuchaeta by the symmetrical genital segment and 3jointed exopod of the 1st leg. The specimen was obtained off the coast of southern Alaska from a depth between 290 and 340 fathoms.

\section{Scottocalanus infrequens, new species}

(Fig. 10, a-h, and 11, a-h)

Occurrence: USNM No. 122571, Albatross Sta. (ref. top lines on p. 275), 1 ad. ㅇ.

Descriptive Notes: Female, $4.76 \mathrm{~mm}$ (holotype, USNM No. 122751).

The body is elongate ovate, about 3 times as long as wide. The head is fused with the 1st thoracic segment; the 4th segment is fused with the 5 th. The proportional lengths of the cephalothorax and abdomen are as 78 to 22 . The head has a triangular median crest. The last thoracic segment is asymmetrical; the right side is acutely pointed, while the left side is narrowly rounded, but is pointed at the distal lateral margin. The rostrum is biramous; it suddenly attenuates in the distal half.

The abdomen is 4-jointed; the segments are in the following proportional lengths:

\begin{tabular}{lrrrrl} 
Segment & $1-2$ & 3 & 4 & 5 & Furca \\
\cline { 2 - 6 } & 44 & 23 & 14 & 8 & $11=100$
\end{tabular}




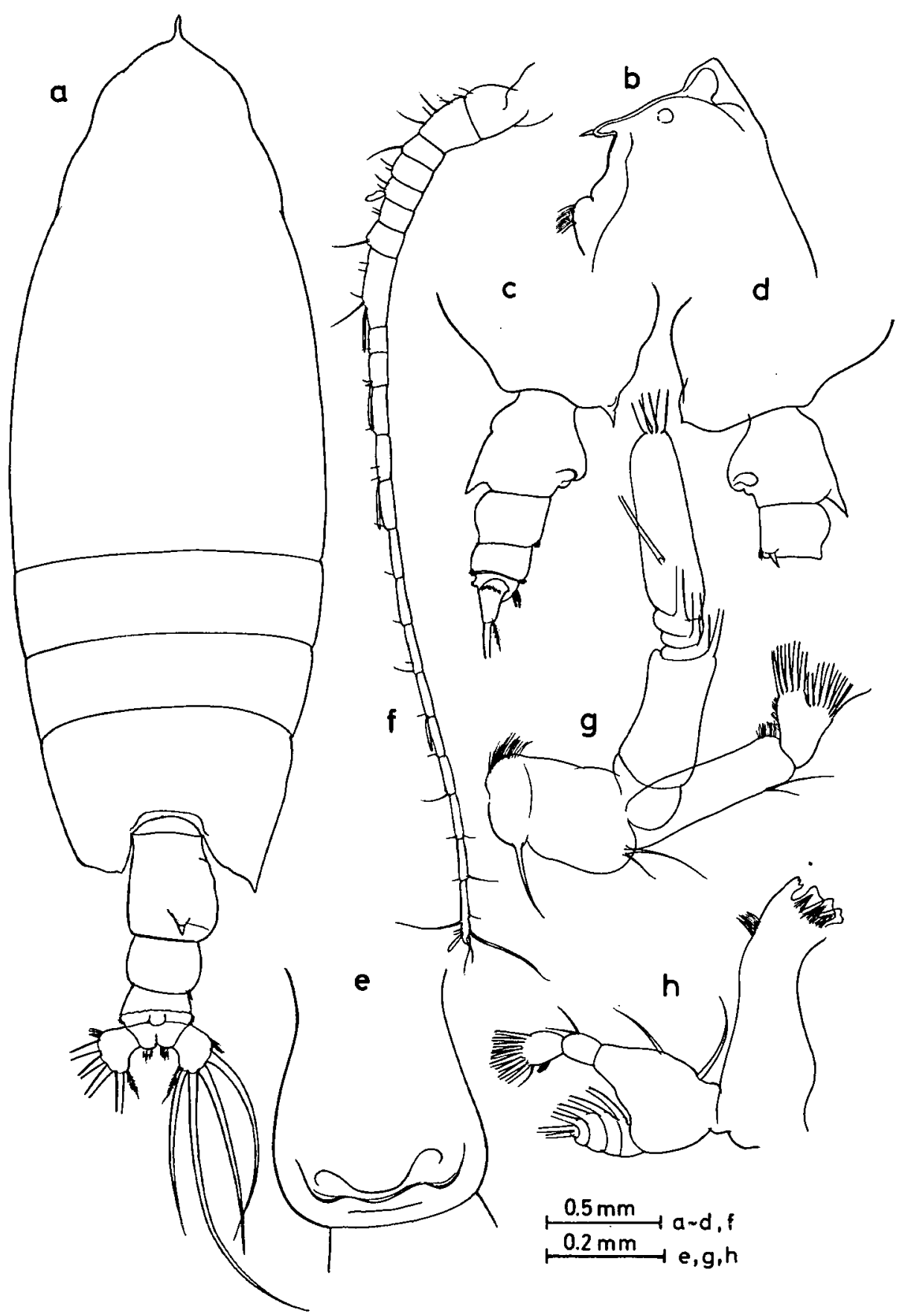

Fig. 10. Scottocalanus infrequens, new species, female: a, whole animal, dorsal view; $b$, head, lateral view; c, last thoracic segment and abdomen, lateral view from right side; d, last thoracic segment and abdomen, lateral view from left side; e, genital segment, ventral view; f, lst antenna; $g$, 2nd antenna; h, mandible. 


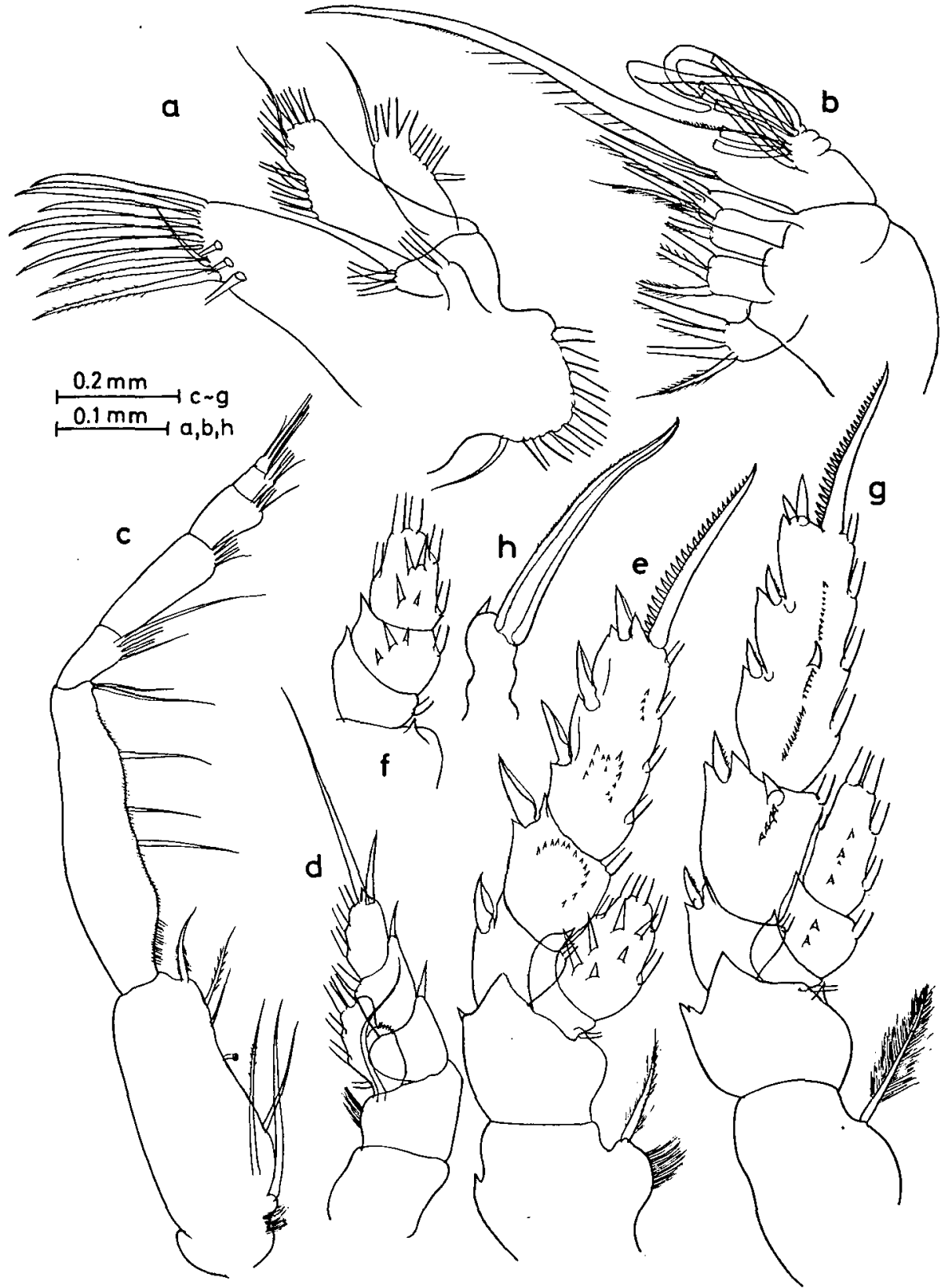

Fig. 11. Scottocalanus infrequens, new species, female: a, 1st maxilla; b, 2nd maxilla; $c$, maxilliped; d, 1st leg; e, 2nd leg; f, 3rd leg, endopod; g, 4th leg; h, left 5th leg.

The genital segment is asymmetrical, swollen on the right lateral margin; a very acute process arises on the dorsal surface near the distal margin; the genital area is considerably produced below. In the 3 rd segment the dorsal surface is swollen; the lateral 
corner is furnished with a small spine on the left side which is accompanied by a bunch of spinules. The 4th segment is dilated on the distal margin, and is furnished with a row of spinules on the lateral margin. The anal segment is furnished with hairs on the distal margin. The furcal ramus is as long as wide, carrying 4 long marginal setae and a small inner marginal one.

The 1 st antenna is 22-jointed, measuring $4.10 \mathrm{~mm}$ in length; the $8 \mathrm{th}, 9 \mathrm{th}$ and 10 th segments as well as the 24th and 25th are fused; it extends to the level where the cephalothorax articulates to the abdomen. The segments are in the following proportional lengths:

\begin{tabular}{lrrrrrrrrrrrrrr} 
Segment & 1 & 2 & 3 & 4 & 5 & 6 & 7 & $8-9-10$ & 11 & 12 & 13 & 14 & 15 \\
\cline { 2 - 10 } & 73 & 56 & 32 & 27 & 29 & 27 & 29 & 86 & 29 & 37 & 49 & 54 & 49
\end{tabular}

\begin{tabular}{|c|c|c|c|c|c|c|c|}
\hline 17 & 18 & 19 & 20 & 21 & 22 & 23 & $24-25$ \\
\hline 46 & 49 & 46 & 49 & 44 & 44 & 44 & $51=1000$ \\
\hline
\end{tabular}

The 2 nd antenna has a 6 -jointed exopod which is 1.5 times as long as the endopod; the endopod has 5 setae on the outer lobe, and 7 setae on the inner lobe. In the mandible the exopod is as long as the endopod. The exopod is 5-jointed, and carries 6 setae. The endopod is 2 -jointed; the 1 st segment has 2 setae; the 2 nd segment has 10 setae on the distal margin. The mandibular palp is furnished with 2 marginal setae. The cutting blade is mutilated in the present specimen. The 1 st maxilla has 9 setae on the outer lobe, 8 on the exopod, $4+3$ setae on the endopod, 5 on the 2 nd basal segment, 3 setae on the 3 rd inner lobe, 2 on the 2 nd inner lobe, and 11 setae on the lst inner lobe. In the 2nd maxilla the endopod is furnished with 8 worm-like filaments; the spine of the 5th lobe is very strong. In the maxilliped the 1st basal segment is robust; the 1st lobe is furnished with, in addition to a long seta, a bunch of hairs; in the 2 nd basal segment the inner margin is provided with a row of spinules. The endopod is 5-jointed; the 2nd segment is very long.

The 1st leg has a 3-jointed exopod and a 1-jointed endopod; the 1st segment of the exopod is swollen on the inner margin. The 2 nd leg has a 3 -jointed exopod and a 2-jointed endopod; the exopod and endopod are furnished with rows of spinules on the posterior surface. The 3rd and 4th legs have 3-jointed exopods and endopods. In the 4th leg the posterior surface of the 2 nd and 3rd segments of the exopod are ornamented with a longitudinal row of spinules; on both segments the row contains a large spine. The 5th leg is 1 -jointed, and is furnished with a strong spine on the inner distal margin of the basal segment, which is much longer than the segment itself. The right 5 th leg was not found in the present specimen.

Remarks: The specimen is easily distinguished from other members of the genus Scottocalanus by the asymmetry of the last thoracic segment and by the structure of the genital and 2nd abdominal segments which are furnished with a remarkable spine respectively. The absence of the right 5 th leg may be abnormal. 
The specimen was obtained at one of the ten Albatross stations in the Pacific Ocean (Stas. 3712, 4757, 4758, 5120, 5185, 5227, 5232, 5233, 5246, and 5263).

\section{Scottocalanus rotundatus TANAKA, 1961}

Scottocalanus rolundatus TANAKA, 1961, p. 147, fig. 109.

Occurrence: USNM No. 122535, Albatross Sta. 5231, 1 ad. ㅇ․

Remarks: The present species is easily distinguished from the other members of the genus by having a rounded forehead in the female.

\begin{tabular}{rllcc}
$r$ Author & \multicolumn{1}{c}{ Locality } & \multicolumn{2}{c}{ Depth } & \multicolumn{2}{c}{ Length $\mathrm{mm}$} \\
& & & + & 0 \\
TANAKA, 1961 & Izu region & $0-1000 \mathrm{~m}$ & 4.07 & 4.38 \\
Present record & Off Philippine & $0-350 \mathrm{fms}$ & - & 4.43
\end{tabular}

\section{Scottocalanus securifrons (T. ScoTT, 1894)}

Scottocalamus securifrons, SARS, 1925, p. 160, pl. 45, figs. 1-8; TANAKA, 1961, p. 141, fig. 106; GRICE, 1962, p. 213, pl. 19, figs. 12-15; Vervoort, 1965, p. 36; OWRE and Foyo, 1967, p. 63, figs. 98, 400-403, 409,410 .

Occurrence: USNM No. 79512, Bache Sta. 10210, 1 ad. $q, 1$ ad. $\hat{0}$.

Remarks: This very common species is easily recognized by the shape of the genital segment and the 5th pair of legs. Some records of occurrence are listed in the following table.

Author

A. ScotT, 1909
With, 1915
SARs, 1925
FARRAN, 1929
SEWELL, 1947
TANAKA, 1961
Grice, 1962
Present record

A. ScotT, 1909

WITH, 1915

SEWELL, 1947

Present record
Locality

Malay Archipelago

North Atlantic

North Atlantic

Off New Zealand

Arabian Sea

Izu region

Equatorial Pacific

Off Bahamas

\begin{tabular}{|c|c|c|}
\hline \multirow[t]{2}{*}{ Depth } & \multicolumn{2}{|c|}{ Length $\mathrm{mm}$} \\
\hline & 우 & o \\
\hline $0-1500 \mathrm{~m}$ & 4.3 & 4.75 \\
\hline $100-600 \mathrm{~m}$ & 4.49 & 4.98 \\
\hline $0-1000 \mathrm{~m}$ & 4.50 & - \\
\hline Surface & $3.88-4.50$ & - \\
\hline $0-500 \mathrm{~m}$ & - & - \\
\hline $0.1000 \mathrm{~m}$ & 4.29 & 4.81 \\
\hline $0-280 \mathrm{~m}$ & 4.08 & \\
\hline- & 4.07 & 3.79 \\
\hline
\end{tabular}

\section{Lophothrix frontalis GIESBRECHT, 1895}

(Fig. 12)

Lophothrix frontalis, A. Scotr, 1909, p. 99, pl. 26, figs. 11-20, pl. 29, figs. 1-10; SARs, 1925, p. 162, pl. 45, figs. 9-21, pl. 46, figs. 1-7; SEwell, 1929, p. 193, figs. 70-73; 1947, p. 148, figs. 37, 38; TANAKA, 1961, p. 150, fig. 110 .

Occurrence: USNM No. 122532, Albatross Sta. 1 juv. $\hat{\delta}$.

Remarks: This is a widely distributed species, occurring in all great oceans. The 
distribution and variation in size are shown in the following table. The present immature specimen is $4.80 \mathrm{~mm}$ in length.

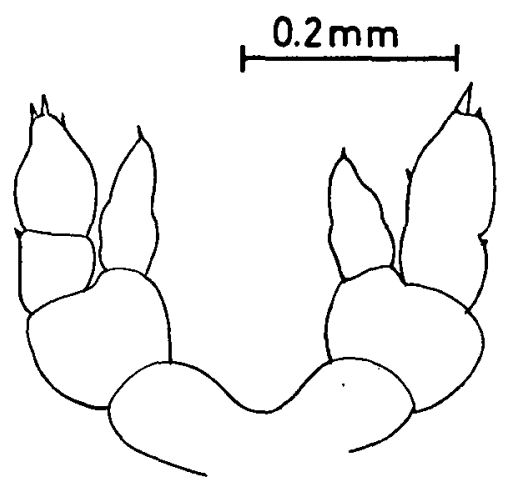

Fig. 12. Lophothrix frontalis GIESBRECHT, immature male: 5 th pair of legs.

Author

A. Sсотт, 1909

WITH, 1915

SARS, 1925

SeWell, 1929

Seweld, 1947

Davis, 1949

TANAKA, 1961

VERVOORT, 1965
Locality

Malay Archipelago

North Atlantic

North Atlantic

Bay of Bengal

Arabian Sea

Northeastern Pacific

Izu region

Gulf of Guinea
Depth

$0-1500 \mathrm{~m}$

$100-800 \mathrm{~m}$

0-1200 m

$-$

0-1500 m

$0-500 \mathrm{~m}$

$0-1000 \mathrm{~m}$

$130-600 \mathrm{~m}$
Length $\mathrm{mm}$

\begin{tabular}{ll}
\multicolumn{1}{c}{ 오 } & \multicolumn{2}{c}{${ }^{\text {क }}$} \\
7.40 & 5.75 \\
6.45 & 5.66 \\
6.30 & 4.50 \\
$4.88-6.13$ & 4.78 \\
$4.75-6.72$ & 4.50 \\
$6.0-7.4$ & 5.5 \\
$5.80-6.90$ & 5.39 \\
$5.30-6.25$ & $4.52-5.73$
\end{tabular}

\section{Scaphocalanus magnus (T. ScoTT, 1894)}

Scaphocalanus magnus, Wrth, 1915, p. 189, text-fig. 58, pl. 7, fig. 8, pl. 8, fig. 6; Sewell, 1947, p. 144, figs. 35, 36; VerVoort, 1957, p. 111; TANAKA, 1961, p. 158, fig. 113.

Occurrence: USNM No. 122535, Albatross Sta. 5785, 1 ad.

Remarks: This well-known species has a very wide distribution, occurring in all great oceans.

Author

EsterLy, 1905

A. ScotT, 1909

WITH, 1915

SeWEll, 1929

Sewell, 1947

Davis, 1949

TANAKA, 1961

VERvoort, 1965

Present record
Locality

San Diego region

Malay Archipelago

North Atlantic

Bay of Bengal

Arabian Sea

Northeastern Pacific

Izu region

Gulf of Guinea

Off Philippine
Depth

$0-400 \mathrm{fms}$
-
-
$0-200 \mathrm{fms}$
$00-685 \mathrm{~m}$
$00-1100 \mathrm{~m}$
$0-1000 \mathrm{~m}$
$0-100 \mathrm{~m}$

Length mm

\begin{tabular}{lc}
\multicolumn{1}{c}{ 而 } & ○ \\
4.4 & - \\
$4.0-4.5$ & 4.5 \\
5.23 & 4.74 \\
4.90 & - \\
$3.55-4.97$ & - \\
$3.7-5.6$ & $4.5-4.8$ \\
$4.39-4.85$ & 4.65 \\
$4.02-4.35$ & - \\
4.43 & -
\end{tabular}




\section{LITERATURE GITED}

Brodsky, K.A. 1950. Copepoda Calanoida of the far eastern seas of USSR and the polar basin. Descriptive list of Fauna of USSR. Izdav. Zool. Inst. Akad. Nauk, SSSR, vol. 35, 442 pp. (In Russian)

Davis, C.C. 1949. The pelagic Copepoda of the northeastern Pacific Ocean. Univ. Wash. Publ. Biol., vol. 14, pp. 1-118.

Esterly, C.O. 1905. The pelagic Copepoda of the San Diego region. Univ. Calif. Publ. Zool., vol: 2, no. 4, pp. 113-233.

1906. Additions to the copepod fauna of the San Diego region. Univ. Calif. Publ. Zool., vol. 3, no. 5, pp. 53-93.

FarRan, G.P. 1929. Crustacea, part 10. Copepoda. Nat. Hist. Rept. Terra Nova Exped., Zool. vol. 8, no. 3, pp. 203-306.

1936. Copepoda. Sci. Rept. Gr. Barrier Reef Exped., vol. 5, no. 3, pp. 73-142.

Giesbrecht, W. 1892. Systematik und Faunistik der Pelagischen Copepoden des Golfes von Neapel. Fauna u. Flora Golf. Neapel, monogr. 19, 831 pp., 54 pls.

Grice, G.D. 1962. Calanoid copepods from equatorial waters of the Pacific Ocean. U.S. Fish Wildlife Serv. Fish. Bull. 186, vol. 61, pp. 167-246.

Grice, G.D. and Hulsemann K. 1967. Bathypelagic calanoid copepods of the western Indian Ocean. Proc. U.S. Nat. Mus., vol. 122, no. 3583, pp. 1-67.

MoRt, T. 1937. The pelagic Copepoda from the neighbouring waters of Japan. Tokyo. 150 pp., 80 pls.

Owre, H.B. and Foyo, M. 1967. Copepods of the Florida Current. Fauna Caribaea, no. 1. Crustacea, part 1. Copepoda. $137 \mathrm{pp}$.

Paiva, I. de, 1963. Contribuicao para o estudo dos Copepodes Calanoides do arquipelago de Cabo Verde. Trab. Cent. Biol. Pisc., no. 42, pp. 1-82.

SARs, G.O. 1925. Copépodes particulierement bathypelagiques provenant des campagnes scientifiques du Prince Albert Ier de Monaco. Result. Camp. Sci. Monaco, vol. 69, text (1925), 408 pp; atlas (1924), 127 pls.

Scotr, A. 1909. The Copepoda of the Siboga Expedition. 1. Free-swimming, littoral and semiparasitic Copepoda. Siboga Exped., monogr. 29a, 323 pp., 69 pls.

Sewell, R.B.S. 1929 and $1932 . \quad$ The Copepoda of Indian Seas. Mem. Indian Mus., vol. 10, pp. 1-221, pls. 1, 2. (1929); pp. 223-407, pls. 3-6. (1932).

- 1947. The free-swimming planktonic Copepoda. Systematic account. Sci. Rep. J. Murray Exped., vol. 8, no. 1, pp. 1-303.

TANaKA, O. 1956. The pelagic copepods of the Izu region, middle Japan. Systematic Account $\mathbf{I}$. Family Calanidae and Eucalanidae. Publ. Seto Mar. Biol. Lab., vol. 5, no. 2, pp. 251-272.

1957. The pelagic copepods of the Izu region, middle Japan. Systematic Account IV. Family Aetideidae (part 2). Publ. Seto Mar. Biol. Lab., vol. 6, no. 2, pp. 169-207.

1961. The pelagic copepods of the Izu region, middle Japan. Systematic Account VII. Family Scolecithricidae (part. 1). Publ. Seto Mar. Biol. Lab., vol. 9, no. 1, pp. 139-190.

TANaKa, O. and OMori, M. 1968. On Euchirella (Copepoda, Calanoida) collected chiefly by the U.S. Steamer Albatross from the Pacific Ocean. Publ. Seto Mar. Biol. Lab., vol. 17, no. 1, pp. 33-65.

Vervoort, W. 1946. The bathypelagic Copepoda Calanoida of the Snellius Expedition, I. Families Calanidae, Eucalanidae, Paracalanidae, and Pseudocalanidae. Temminckia, vol. 8, pp. 1-181. - 1957. Copepods from Antarctic and sub-antarctic plankton samples. Rep. B.A.N.Z. Antarct. Res. Exped., Ser. B, vol. 3, pp. 1-160, figs. 1-138.

1963. Pelagic Copepoda, part I. Copepoda Calanoida of the families Calanidae up to and including Euchaetidae. Atlantide Rept., no. 7, pp. 77-194.

1965. Pelagic Copepoda, part II. Copepoda Calanoida of the families Phaennidae up to and including Acartiidae, containing the description of a new species of Aetideidae. Atlantide Rept. no. 8, pp. 9-216. 
Wilson, C.B. 1932. The copepods of the Woods Hole region, Massachusetts. U.S. Nat. Mus. Bull. 158,635 pp., 41 pls.

1942. The copepods of the plankton gathered during the last cruise of the Carnegie. Scientific results of cruise VII of the Carnegie during 1928-1929 under command of Capt. J.P. Ault. Carnegie Inst. of Washington, Publ. 536, 237 pp.

1950. Copepods gathered by the U.S. Fisheries Steamer Albatross from 1887 to 1909, chiefly in the Pacific Ocean. Bull. U.S. Nat. Mus. 100, vol. 14, pt. 4, pp. 141-441, pls. 1-36.

WITH, C. 1915. Copepoda I, Calanoida Amphascandria. Dan. Ingolf Exped., vol. 3, pt. 4, pp. 1-260, pls. 1-9.

Wolfenden, R.N. 1911. Die marinen Copepoden der Deutschen Südpolar Expedition 1901-1903, II. Die pelagischen Copepoden der Westwinddrift und des südlichen Eismeeres. Deutsch. Südpolar Exped., vol. 12, pp. 181-380, pls. 22-41. 